\title{
Habitat Suitability Index for the \\ Northern Leopard Frog in Alberta: Model Derivation and Validation
}

Fish \& Wildlife Division

\section{SPECIES AT RISK}

Government of Alberta
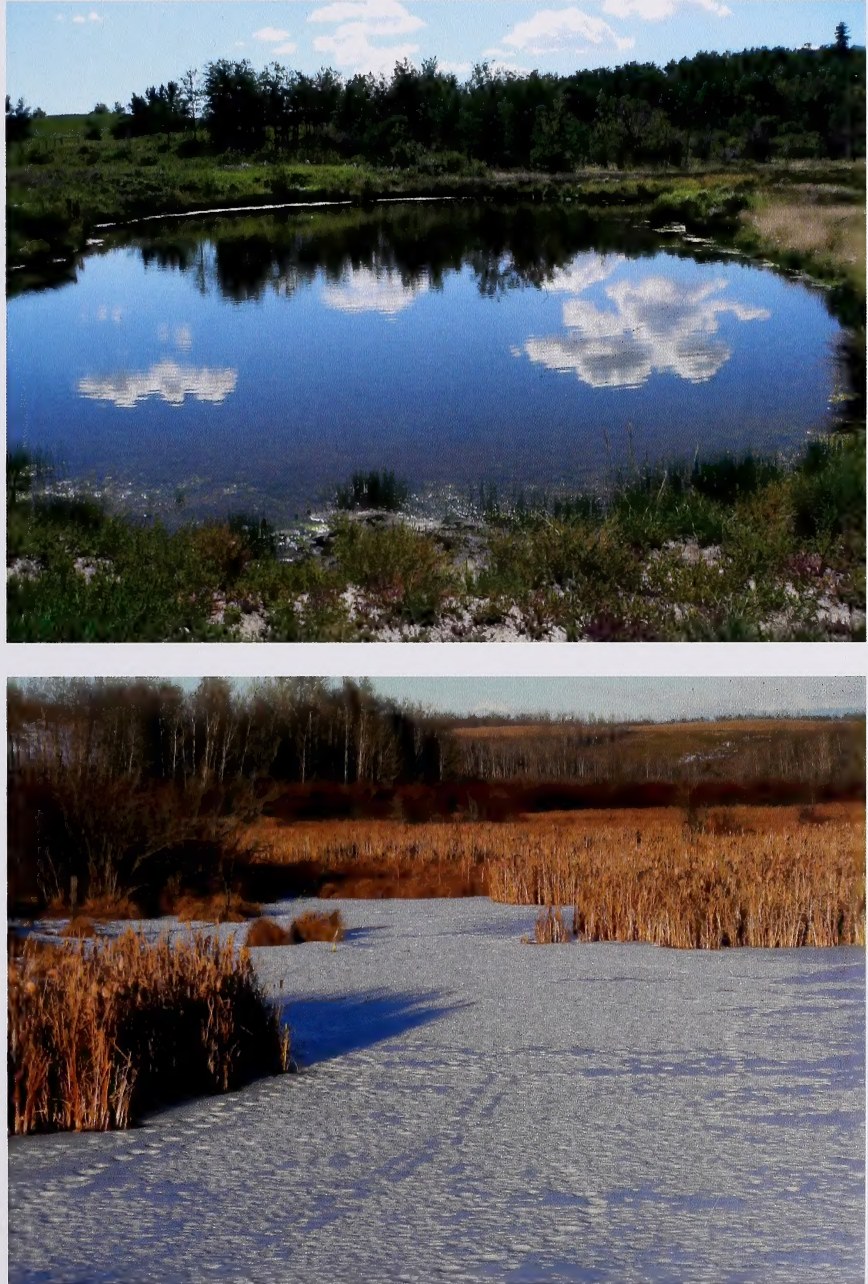

Alberta Species at Risk Report No. 132 
Digitized by the Internet Archive in 2016 


\section{Habitat Suitability Index for the Northern Leopard Frog in Alberta: Model Derivation and Validation}

\section{${ }^{1}$ Scott D. Stevens, ${ }^{2}$ Don Page, and ${ }^{1}$ David R.C. Prescott}

\footnotetext{
${ }^{1}$ Alberta Sustainable Resource Development, Fish and Wildlife Division, \#404-4911 51st Street, Red Deer, Alberta, Canada T4N 6V4

${ }^{2}$ Alberta Environment, Strategic Support and Integration Division, 492051 Street, Red Deer, Alberta, Canada T4N 6K8
}
Alberta Species at Risk Report No. 132 March 2008

\section{Government of Alberta}


ISBN: 978-0-7785-9030-9 (Printed Edition)

ISBN: 978-0-7785-9031-6 (On-line Edition)

ISSN: 1496-7219 (Printed Edition)

ISSN: 1496-7146 (On-line Edition)

Cover Photographs: Scott Stevens

For copies of this report, contact:

Information Centre - Publications

Alberta Environment / Alberta Sustainable Resource Development

Main Floor, Great West Life Building

9920108 Street

Edmonton, Alberta, Canada T5K 2M4

Telephone: (780) 422-2079

OR

Visit our web site at:

http://srd.alberta.ca/BioDiversityStewardship/SpeciesAtRisk/Default.aspx

A complete list of reports in this series can be viewed at:

http:// srd.alberta.ca/BiodiversityStewardship/SpeciesAtRisk/ProgramReports.aspx

This publication may be cited as:

Stevens, S.D, D. Page, and D.R.C. Prescott. 2010. Habitat suitability index for the northern leopard frog in Alberta: model derivation and validation. Alberta Sustainable Resource Development, Fish and Wildlife Division, Alberta Species at Risk Report No. 132, Edmonton, AB. 16 pp. 


\section{TABLE OF CONTENTS}

LIST OF FIGURES AND TABLES...................................................................

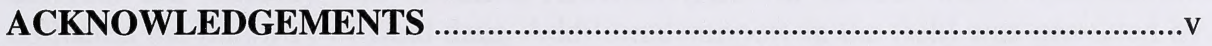

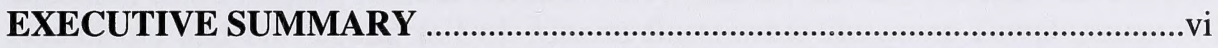

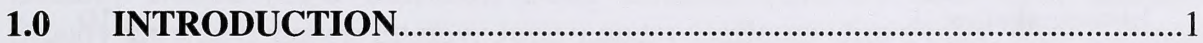

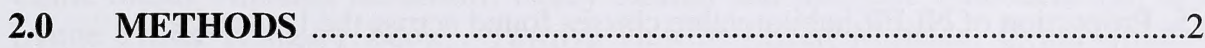

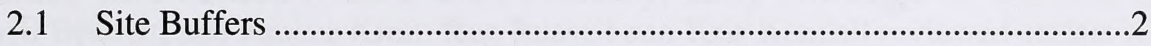

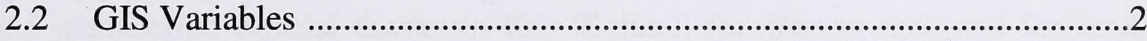

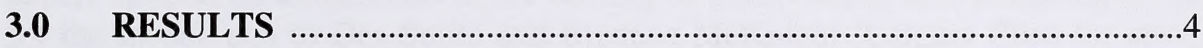

3.1 Comparison of Occupied and Unoccupied Site Buffers ............................

3.2 Model Development and Map Production …………….................................

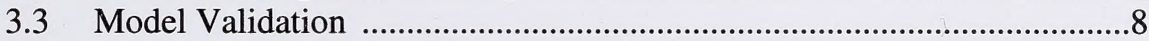

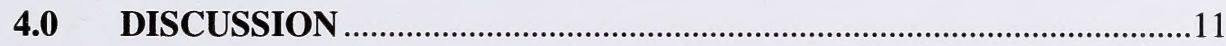

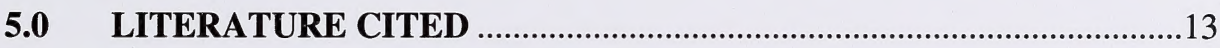




\section{LIST OF FIGURES AND TABLES}

Figure 1. Relationship between suitability scores and habitat variables ..................6

Figure 2. Northern leopard frog habitat suitability map, first run ............................9

Figure 3. Example of HSI model validation............................................................10

Figure 4. Proportion of NLFR habitat value classes found within $200 \mathrm{~m}$ of

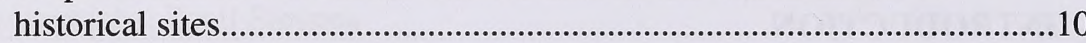

Figure 5. Proportion of NLFR habitat value classes found across the landscape, within $200 \mathrm{~m}$, and within $3 \mathrm{~km}$ of new FWMIS observations

Table 1. GIS variables used in the formation of the HSI model .5 


\section{ACKNOWLEDGEMENTS}

The following individuals were instrumental in the successful completion of the 2005 Alberta northern leopard frog provincial survey, from which habitat model variables were derived. Ian Gazeley and Amanda Krowski (Alberta Conservation Association-ACA) collected the majority of field data. Additional support in the field was provided by Steve Brechtel, Ken Froggatt, Marcie Gareau, Gerry Haekel, Edward Hofman, Ed Karpuk, Joel Nicholson, and Pat Young (all of Alberta Sustainable Resource Development-ASRD), Delaney Burton (CFB Suffield), Doug Collister (URSUS Ecosystem Management), Brandy Downey, Lance Engley, Julie Landry-BeBoer, Jim Potter, Roy Schmelzeisen, Callie Smith, Amanda Rezansoff, Corey Skiftun and Michelle Thibodeau (all of ACA), Lynne Fraser (Calgary Zoo), , Tawnya Hewitt, Eileen Miranda, Cyndi Smith (Parks Canada), Kim Pearson (NCC), Janey Podlubny, Larry Powell (U of C), (Nik Barnes, Lloyd Bennett, and Amber Kreft. Reg Russell and Kris Kendell reviewed earlier versions of the manuscript. Special thanks to Kris Kendell for sharing data and for lending his expert opinion on amphibians in the scoring of index values and weighting of variables for the model, and to Des Smith and Breanna McKnight (Calgary Zoo) for providing a portion of their data from 2009 surveys used in validation of the model. 


\section{EXECUTIVE SUMMARY}

Alberta's northern leopard frog recovery plan identifies habitat modelling as an action item. A habitat model could aid in predicting location of sites that support previously unknown populations and as a tool in the assessment of reintroduction sites. Habitat Suitability Index (HSI) models were developed by the U.S. Fish and Wildlife Service to assess environmental impacts and have been used by Alberta Fish and Wildlife to prioritize the landscape within the Multiple Species at Risk (MULTISAR) project area in southern Alberta.

In 2005, a detailed population survey was undertaken to document the distribution and abundance of current northern leopard frog populations in Alberta. That data provided background for a number of management and research initiatives listed in the recovery plan, and was instrumental in the development of the northern leopard frog HSI model reported here. Potential GIS variables were evaluated by comparing occupied and unoccupied northern leopard frog sites from the 2005 province-wide survey, assuming that differences in those variables could be contributing factors to the demise of populations at vacant sites, and thus could be important indices of habitat suitability. The strongest differences between occupied and unoccupied northern leopard frog sites occurred for perennial hydrological variables, road density, moisture index, and vegetative site characteristics from the Native Prairie Vegetation Index (NPVI; graminoid cover, riparian cover, wetland cover). Due to those differences, hydrological variables and road density became the principal components of the habitat model. Additional variables were incorporated into the model as a cumulative function (NPVI, soil type, soil salinity). Three iterations of the model were created by varying the weight applied to each variable. In the first run each term was given equal weighting, which produced the lowest proportion of high suitability habitat and, therefore, the most utility since a smaller proportion of the landscape can be surveyed to validate the model.

We used two data sets to test the model. First, 59 historical sites have been surveyed for northern leopard frogs since the 2005 survey. Using the HSI model, we classified the maximum habitat value within $200 \mathrm{~m}$ and $3 \mathrm{~km}$ of each point location and compared proportions of habitat types between sites where northern leopard frogs were observed or not detected. Sites where northern leopard frogs were observed had a significantly higher proportion of high HSI values at both the $200 \mathrm{~m}$ and $3 \mathrm{~km}$ scales. Secondly, we classified habitat type across the entire landscape within the northern leopard frog range in Alberta. Proportions of habitat values were compared to new northern leopard frog observations submitted to the Fish and Wildlife Management Information System (FWMIS) between 2006 and 2009, which were not used in development of the model. Again, the proportion of classes of high habitat value was significantly higher at both scales than what is available on the landscape. These two lines of validation indicate the model appears to have some predictive power. In hopes of locating new populations, the model will be applied in the 2010 northern leopard frog provincial survey, to target specific areas in sub-drainages that have received little attention in the past. 


\subsection{INTRODUCTION}

The northern leopard frog has been considered At Risk in Alberta since 1991, and was designated as Threatened under Alberta's Wildlife Act in 1996 (Alberta Environmental Protection 1996). The Committee on the Status of Endangered Wildlife in Canada (COSEWIC) lists the prairie population of the northern leopard frog as Special Concern (COSEWIC 2002). In 2004, Alberta's Minister of Sustainable Resource Development reaffirmed the listing of the northern leopard frog and formally initiated recovery efforts in the province. The Alberta Northern Leopard Frog Recovery Plan 2005-2010 (ANLFRT 2005) was approved for implementation in 2005.

Alberta's northern leopard frog recovery plan identifies habitat modelling as an action item. A habitat model could aid in predicting location of sites that support previously unknown populations and as a tool in the assessment of reintroduction sites. Habitat Suitability Index (HSI) models were developed by the U.S. Fish and Wildlife Service to assess environmental impacts (USDI Fish and Wildlife Service 1981, Berry 1986) and have been used by Alberta Fish and Wildlife to prioritize the landscape within the Multiple Species at Risk (MULTISAR) project area in southern Alberta (Downey et al. 2004). The HSI is an efficient and inexpensive method for determining habitat quality, especially when linked to remote sensing. HSI models are derived from quantitative accounts and expert opinion regarding a species' habitat preferences (Morrison et al. 1992, Jones 2004) and work by assigning habitat components values from 0 to 1 , where a rating of 1 is considered optimal habitat and a rating of 0 is considered unsuitable (USDI 1981, Jones 2004). Habitat variables can be selected from Geographic Information System (GIS) databases and are chosen based on their ability to represent important habitat features for a selected species; they are generally physical, chemical, or biological in nature (USDI 1981, Bessie et al. 1996). Spatial variables take the form of distance to or from a particular feature (e.g. distance from roads) and can be used to modify habitat availability parameters (Jones 2004). Variables for the model are combined using a mathematical equation to produce the habitat suitability index. Although northern leopard frog habitat has been modelled for other areas (e.g., Washington, Germain and Hays 2009; Idaho, Blomquist and Hunter 2009), we are not aware of any habitat suitability models for Alberta, particularly for the entire extent of the range.

The northern leopard frog requires a mosaic of habitat types to meet the annual requirements of all life its history stages, including breeding, summer foraging, and overwintering (Souder 2000, Kendell 2003). Breeding occurs in shallow and warm standing water associated with permanent and semi-permanent wetlands, springs, dugouts, borrow pits, lakes, beaver ponds and the backwaters and oxbows of rivers (Wershler 1992a, Seburn and Seburn 1998, Kendell 2003). Preferred summer feeding habitat generally consists of open and semi-open areas with short vegetation (Wershler 1992a, Kendell 2003). Unlike most of Alberta's other amphibian species, northern leopard frogs require well-oxygenated water that does not freeze to the bottom during the winter (Hine et al. 1981). Hibernacula are most often located in springs, streams, spillways below dams, or in deeper lakes and ponds (Roberts 1981). For this reason, any habitat model for northern leopard frogs must make the presence of permanent water bodies a key habitat variable. 
Climatic conditions (Merrell 1977), habitat fragmentation (Pope et al. 2000), habitat loss to agriculture and practices associated with intense agriculture (e.g. fertilizers, pesticides; Carr and Fahrig 2001, Houlahan et al. 2001), and roads (Yaremko 1997; Carr and Fahrig 2001, Houlahan et. al 2001, Mazerolle et al. 2005) have all been shown to affect northern leopard frogs and are factors to consider in a habitat model for the species.

In 2005, a province-wide survey for northern leopard frogs was conducted by the Alberta Conservation Association (ACA) and Alberta Sustainable Resource Development (ASRD). The intent of the survey was to assess population status and provide baseline information for reintroduction of northern leopard frogs, and formation of stewardship agreements at sites with habitat threats (Kendell et al. 2007). Northern leopard frogs were detected at only 76 of 181 (42\%) historical locations obtained from the Alberta Fish and Wildlife Information System-FWMIS. Potential GIS variables were evaluated by comparing occupied and unoccupied northern leopard frog sites from the 2005 survey. We assumed that differences in these variables could be contributing factors to the demise of populations at vacant sites, and thus could be important indices of habitat suitability.

\subsection{METHODS}

\section{$\underline{2.1 \text { Site buffers: }}$}

Northern leopard frog sites, occupied ( $n=76)$ or unoccupied $(n=105)$, were buffered by 3 $\mathrm{km}$, the approximate maximum dispersal distance for northern leopard frogs (Seburn et al. 1997). When buffers from two or more sites overlapped, they were amalgamated into a single polygon. If an occupied and unoccupied site buffer overlapped, the unoccupied site was dropped from the analysis. A total of 53 buffer polygons for occupied sites and 99 for unoccupied sites were derived.

\subsection{GIS Variables:}

Base data was provided to the ASRD Resource Information Unit by the Spatial Data Warehouse Ltd.

\section{Single Line Network (SLNet)}

SLNet represents rivers and streams that are too small to capture as polygons. They also contain "Representational Flow Lines" which are lines running through polygons such as rivers and lakes. These provide "connectivity" so that a network can be made to connect all features in a continuous flow. To control for variation in buffer size, the total length of SLNet (m) was calculated for each buffer and divided by buffer area (ha). SLNet includes many habitat features that are periodically dry, including ditches and ephemeral streams. Although such features may be temporarily available to amphibians, northern leopard frogs rely on permanent water for over-wintering, so the analysis was also done for selected permanent features (perennial lakes, rivers, streams, and canals). 
Hydro polygons capture rivers greater than $20 \mathrm{~m}$ wide and water bodies greater than two hectares. Once intersected with buffers, the resulting dataset contains only the features that fall within the buffer. To control for variation in buffer size, total area of hydro polygons $\left(\mathrm{m}^{2}\right)$ was calculated for each site buffer and divided by site buffer area (ha). Because hydro polygons also include basins and features that are periodically dry (lakes, sloughs, etc.), and thus unavailable as habitat for northern leopard frogs, the following permanent water bodies were selected from the GIS layer: creeks, dugouts, lagoons, lakes, quarrys, oxbows, rivers, and reservoirs. Since northern leopard frogs generally use the perimeter of waterbodies, hypolygon perimeter was calculated and expressed as perimeter density (length perimeter divided by buffer area).

\section{Distance from site buffer to nearest permanent hydrography}

Because northern leopard frogs require permanent waterbodies for overwintering, we compared the distance from permanent hydrography for occupied and unoccupied sites, assuming that some historical locations may no longer be associated with permanent waterbodies due to drought, drainage, and water diversion. Distance between feature locations and nearest permanent hydrography (SLNet or hydro polygon) was calculated by using the "Near" Command in ArcInfo Workstation. Occupied and unoccupied site buffers were run on the following criteria: 1) a comparison using all SLNet arcs; 2) a comparison using only perennial SLNet arcs; 3 ) a comparison using arcs from all hydropolygons; 4) a comparison using arcs from perennial hydropolygons.

\section{Roads}

Road data were derived from a Base Features Road layer, intersected with site buffers, and clipped to the buffer. This is an identical concept to SLNet. Total road length (m) in each site buffer was calculated and divided by buffer area (ha), thus units are meters of road per hectare of site buffer.

\section{Climate}

Climate data was provided by the Alberta Forest Management Branch (FMB) and are ArcInfo Grids with a cell size of $500 \mathrm{~m}$. Buffer polygons were rasterized to the same cell size as the climate data. Zonal polygons were created based on site buffer and "ZonalStats" were then run on each of the following climate datasets to calculate the Min, Max, and mean for each buffer, and to compare occupied and unoccupied site buffers: length of frost-free period (days), annual moisture index (degree days $>5^{\circ} \mathrm{C} /$ mean annual precipitation-November 2003 ArcInfo model), mean annual precipitation $(\mathrm{mm})$, and mean annual temperature $\left({ }^{\circ} \mathrm{C}\right)$. 
The Native Prairie Vegetation Inventory (NPVI) was clipped by occupied and unoccupied buffers using the ArcInfo "Intersect" command. Because the NPVI is a quarter-section dataset that describes the percentages of different land covers in each quarter section, it will only give an approximation of the various land covers. Percent coverage of the following habitat types were compared between occupied and unoccupied site buffers: graminoid, lake, riparian, shrub, treed, and wetland.

\section{Soils}

Soils data was taken from Alberta Agriculture, Food and Rural Development (2005). Datasets for soil salinity and solonetzic soils were intersected with each site buffer. Saline soils are non-alkali $(\mathrm{pH} \leq 8.5)$ and contain soluble salts in great enough quantities that they interfere with the growth of most crop plants. The areal extent of saline soils within each Agricultural Region of Alberta Soil Inventory Database (AGRASID) soil landscape polygon was represented as a percentage of the total area using the categories greater than $30 \%$ and $10-30 \%$.

Solonetzic soils develop on saline parent material that is high in sodium and have a characteristic hardpan layer that has formed in the subsoil. This hardpan is very hard when dry and has low permeability when wet. AGRASID soil landscape polygons that contained soils belonging to the Solonetzic Order were identified, and the areal extent of these soils was represented as a percentage of the total area using the categories greater than $30 \%$ and $10-30 \%$. All sites with no data for these parameters had less than $10 \%$ solonetzic soils.

\section{Data Analysis}

Data derived from GIS variables at occupied and unoccupied site buffers were not normally distributed. Further, since sample sizes differed substantially between occupied and unoccupied buffers, a non-parametric Mann-Whitney U-test (Zar 1974) was used to compare means of all variables, except soil characteristics. Because many site buffers contained soils with salinity greater than $10 \%$, and no solonetzic soils, a comparison of the proportion of site buffers was done (Fisher Exact test; Zar 1974).

\subsection{RESULTS}

\section{$\underline{3.1 \text { Comparison of GIS Variables at Occupied and Unoccupied Site Buffers }}$}

The strongest differences between occupied and unoccupied northern leopard frog sites occurred for distance of site from permanent SLnet and road density; occupied sites were found to be closer to perennial streams or rivers and generally occurred where road density was low $(\mathrm{p}<0.05$; Table 1$)$. Occupied site buffers also had greater permanent SLnet and hydropolygon perimeter density than unoccupied sites. Due to these differences, hydrological variables and road density became the principal components of 
the habitat model. These variables were incorporated into the model as a cumulative function (sums the values of two or more variables).

Moisture index, mean annual temperature, and NPVI values for graminoid cover, riparian cover, and wetland cover also differed substantially between occupied and unoccupied sites $(\mathrm{p}<0.05$; Table 1$)$. Although differences in soil salinity and proportion of solonetzic soils were not significant, we kept them in the model to because soil characteristics have been shown to affect amphibian distributions (Piha et al. 2007, Mazerolle and Villard 1999, Frisbie and Wyman 1982). Therefore, HSI values were generated based on the distribution of soil salinity and type found at occupied sites.

Table 1. GIS variables used in the formation of the HSI model and comparisons of those attributes between occupied and unoccupied northern leopard frog site buffers.

\begin{tabular}{|c|c|c|c|c|c|c|c|}
\hline \multirow{2}{*}{$\begin{array}{l}\text { Variable } \\
\text { Number }\end{array}$} & \multirow[b]{2}{*}{ GIS Attribute } & \multicolumn{2}{|c|}{ Occupied } & \multicolumn{2}{|c|}{ Unoccupied } & \multirow[b]{2}{*}{ test-statistic } & \multirow[b]{2}{*}{ p-value } \\
\hline & & Mean & SE & Mean & SE & & \\
\hline V1 & $\begin{array}{c}\text { Distance from } \\
\text { permanent SLnet (m) }\end{array}$ & 413 & 54 & 1100 & 120 & $\mathrm{Z}=4.6$ & $<0.00001$ \\
\hline $\mathrm{V} 2$ & $\begin{array}{l}\text { Permanent SLnet } \\
\text { density }(\mathrm{m} / \mathrm{ha})\end{array}$ & 5.4 & 0.5 & 3.8 & 0.3 & $\mathrm{Z}=2.79$ & 0.005 \\
\hline V3 & $\begin{array}{l}\text { Permanent hydropolygon } \\
\text { permimeter density ( } \mathrm{m} / \mathrm{ha} \text { ) }\end{array}$ & 4.6 & 0.6 & 3.9 & 0.5 & $\mathrm{Z}=1.85$ & 0.02 \\
\hline V4 & Road density (m/ha) & 3.3 & 0.4 & 9.6 & 0.6 & $Z=6.98$ & $<0.00001$ \\
\hline V5 & Moisture Index & 4.8 & 0.1 & 4.1 & 0.1 & $\mathrm{Z}=3.22$ & 0.0012 \\
\hline V6 & Mean Annual Temperature $\left({ }^{\circ} \mathrm{C}\right)$ & 4.3 & 0.1 & 3.9 & 0.1 & $\mathrm{Z}=2.23$ & 0.024 \\
\hline V7 & Graminoid cover $(\%)$ & 50.8 & 4.1 & 37.3 & 3.0 & $Z=2.73$ & 0.006 \\
\hline V8 & Riparian cover (\%) & 3.4 & 0.6 & 2.6 & 0.3 & $\mathrm{Z}=1.83$ & 0.07 \\
\hline V9 & Wetland cover (\%) & 2.9 & 0.3 & 2.3 & 0.3 & $\mathrm{Z}=2.33$ & 0.02 \\
\hline V10 & *Soil Salinity $(10-30 \%)$ & 55 & - & 40 & - & Fisher Exact & 0.12 \\
\hline & Soil Salinity $(30-100 \%)$ & 38 & - & 24 & 一 & Fisher Exact & 0.09 \\
\hline V11 & *Solonetzic soils $(30-100 \%)$ & 49 & - & 39 & - & Fisher Exact & 0.30 \\
\hline
\end{tabular}

\subsection{Model Development and Map Production}

The northern leopard frog HSI model was developed by using GIS characteristics that differed between unoccupied and occupied sites as these should indicate higher suitability at occupied sites. Distribution curves of those variables were produced and HSI values were assigned a weighted value (Figure 1). GIS layers were then combined using "Map Algebra" formulas to determine the theoretical site potential. Three models were run with the values weighted differently in each run. The HSI model was projected onto the southern third of the province, from roughly $53^{\circ} \mathrm{N}$ south to the Canadian-American 
border $\left(49^{\circ} \mathrm{N}\right)$. With the exception of montane habitat, that area is roughly equivalent to the current range of northern leopard frogs in Alberta (Kendell et al. 2007).

Figure 1. Relationship between suitability scores and habitat variables.

V1 Distance from Permanent SLNet

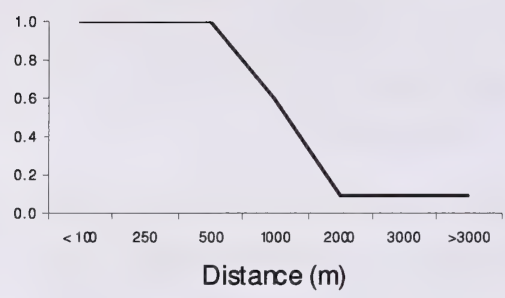

V3 Permanent Hydro perimeter density

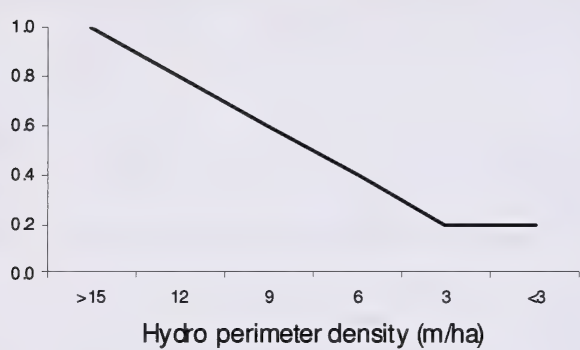

V5 Moisture Index

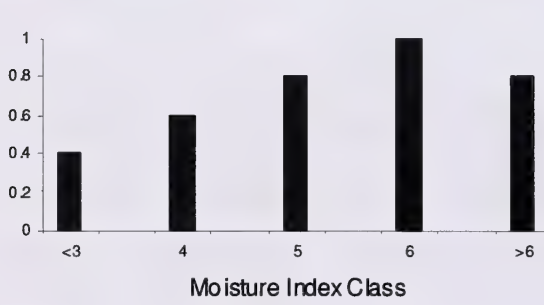

V7\%Graminoid Cover

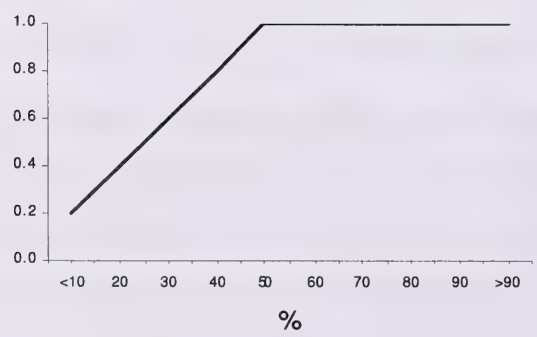

V2 Permanents SLNet Density

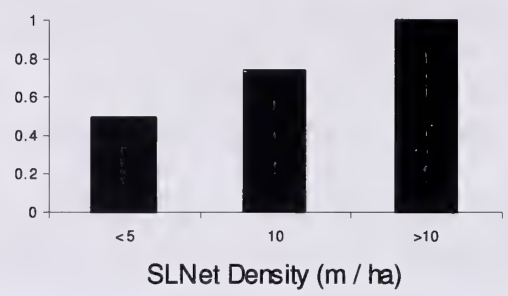

V4 Road Density

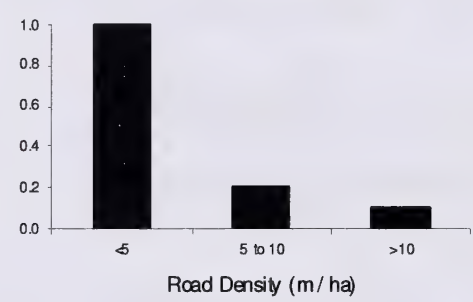

V6 Mean Annual Temperature

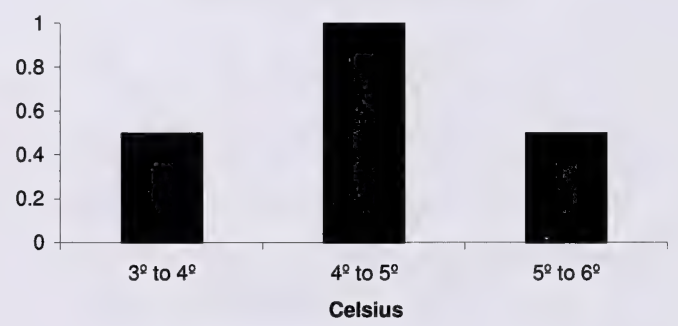

V8 \%Riparian Cover

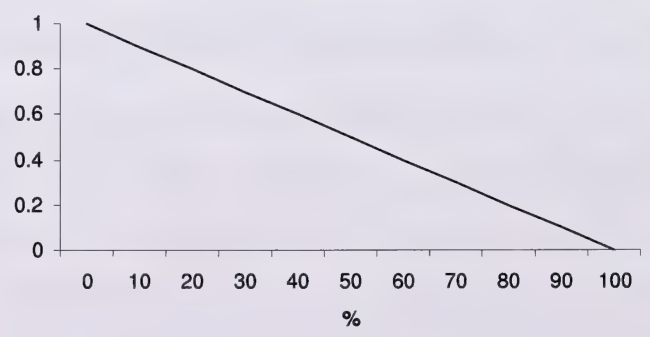



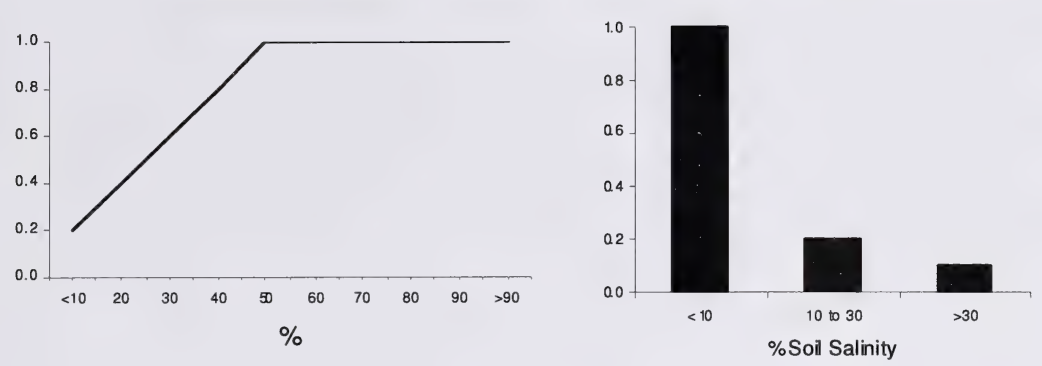

V11 Solonetzic Soils

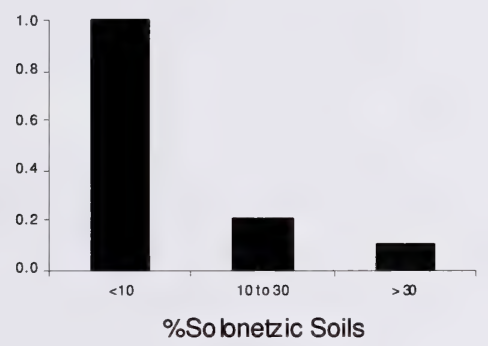

The equation used to combine variables must take into account how the species utilizes the different variables in its habitat. There are 3 guidelines used in determining the appropriate equation (Bessie et al. 1996). First, the level of interaction between variables determines how they are combined (additive or multiplied). Second, one variable may compensate for another and determines whether one variable increases the effect of another. Last, different weightings can be applied to certain variables to reflect their importance. Basic equations used to combine the variables are: 1) cumulative relationship (additive; sums the values of two or more variables when there is no interaction between variables); 2) complete interaction (multiply; occurs when there is complete interaction of all variables; 3 ) limiting factors (minimum function; a variable with lowest suitability overrides all other factors and is often used when more than one model is developed for different life requisites); 4) compensatory relationships (when a variable with low value is offset by high suitability of other variables.

Since this model was required to be projected over a large geographical area, and was meant as a tool for identifying overall northern leopard frog habitat (i.e. not selecting for breeding habitat), we utilized a cumulative relationship between the principal hydrological and road variables. Moisture index through soil type were integrated by a compensatory relationship and added as a combined term such that:

$$
\mathrm{HSI}=\mathrm{V}_{1}+\mathrm{V}_{2}+\mathrm{V}_{3}+\mathrm{V}_{4}+\left(\underline{\mathrm{V}}_{\underline{5}}+\mathrm{V}_{6}+\mathrm{V}_{7}+\frac{\mathrm{V}_{8}}{7} \underline{\mathrm{V}_{9}}+\mathrm{V}_{10}+\mathrm{V}_{11}\right)
$$


Three iterations of the model were created by varying the weight applied to each variable. In the first run each term was given equal weighting (i.e., 0.2, as total cannot exceed 1). In the second run, the weighting of distance from permanent SLnet $\left(\mathrm{V}_{1}\right)$ was increased to 0.4 , while road density and the compensatory term were reduced to 0.1 . In the third run, SLnet was increased to 0.3 while the compensatory term was decreased to 0.1 . HSI values were partitioned into five habitat classes $(0-0.29 ; 0.30-0.49 ; 0.50-0.69 ; 0.70-0.89$; 0.90-1.0). The second and third runs tended to label all permanent drainages as "high" quality habitat, thus we determined that the first run has the most utility as it targets a smaller proportion of the landscape (Figure 2).

\section{$\underline{\text { 3.3 Model Validation }}$}

We used two data sets to test the model. First, 59 historical sites (pre-1990) not visited during the 2005 survey have since been surveyed for northern leopard frogs; 36 by Alberta Conservation Association / Sustainable Resource Development in 2007 (Prescott and Kendell; unpublished data) and 23 by the Calgary Zoo in 2009 (Smith and McKnight; unpublished data). Data from those two studies were pooled for the analysis: northern leopard frogs were present at 11 of those sites and not detected at 48 sites. Using the HSI model, we classified the maximum habitat value within $200 \mathrm{~m}$ and $3 \mathrm{~km}$ of each point location (Figure 3) and compared proportions of habitat types between sites where northern leopard frogs were observed, and where they were not detected (Figure 4). Sites where northern leopard frogs were detected had a significantly higher proportion of high HSI values at both the $200 \mathrm{~m}\left(X^{2}=185, p<.0005\right.$; Figure 4) and $3 \mathrm{~km}$ scales $\left(X^{2}=54.8\right.$, $\mathrm{p}<0.005)$.

Secondly, we summarized the classification of habitat values into percentages across the entire landscape within the northern leopard frog range in Alberta. Those proportions were compared to new northern leopard frog observations submitted to FWMIS between 2006 and 2009, which were not used in development of the model $(n=26)$. Again, habitat values were classified as maximum value within $200 \mathrm{~m}$ or $3 \mathrm{~km}$ of FWMIS observations. The proportion of habitat classes 4 and 5 were significantly higher, at both scales, than what is available on the landscape $\left(X^{2}{ }_{200 m}=185, p<0.0005 ; X^{2}{ }_{3 k m}=538, p<0.0005\right)$. 


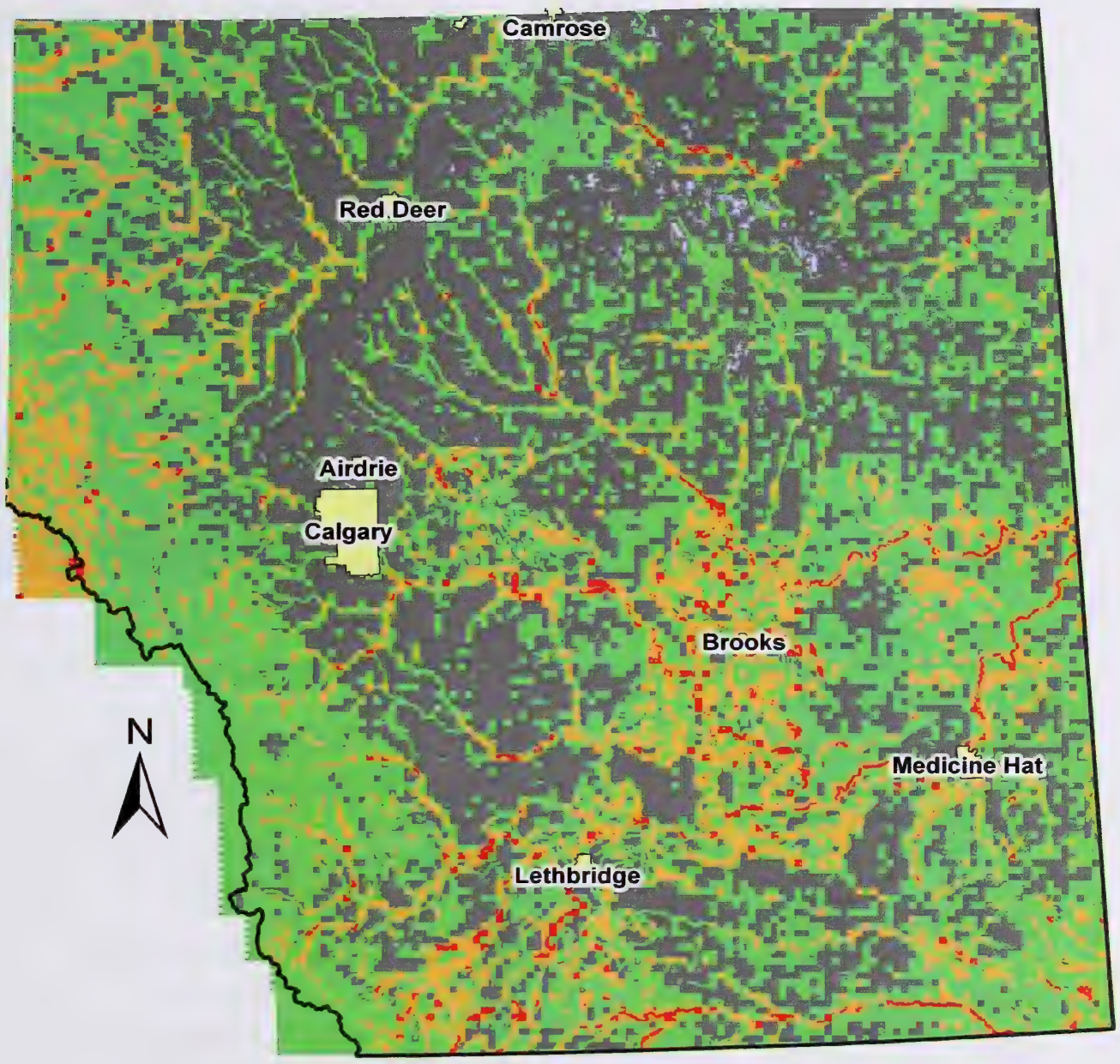

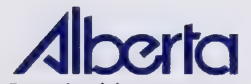

Sustainable Resource

Development

Map Copyright Government of Alberta 2007

Base Data Provided by the Spatial Data Warehouse Lid.

The Minister and the Crown provides this information

without warranty or representation as to any matter

including but not limited to whether the data / information

is correct, accurate or free from error, defect, danger,

or hazard and whether it is otherwise useful or suitable

for any use the user may make of it.

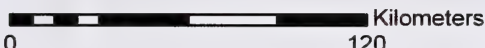

\section{NLFR HSI Values}

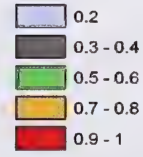

Figure 2. Northern leopard frog habitat suitability map. 

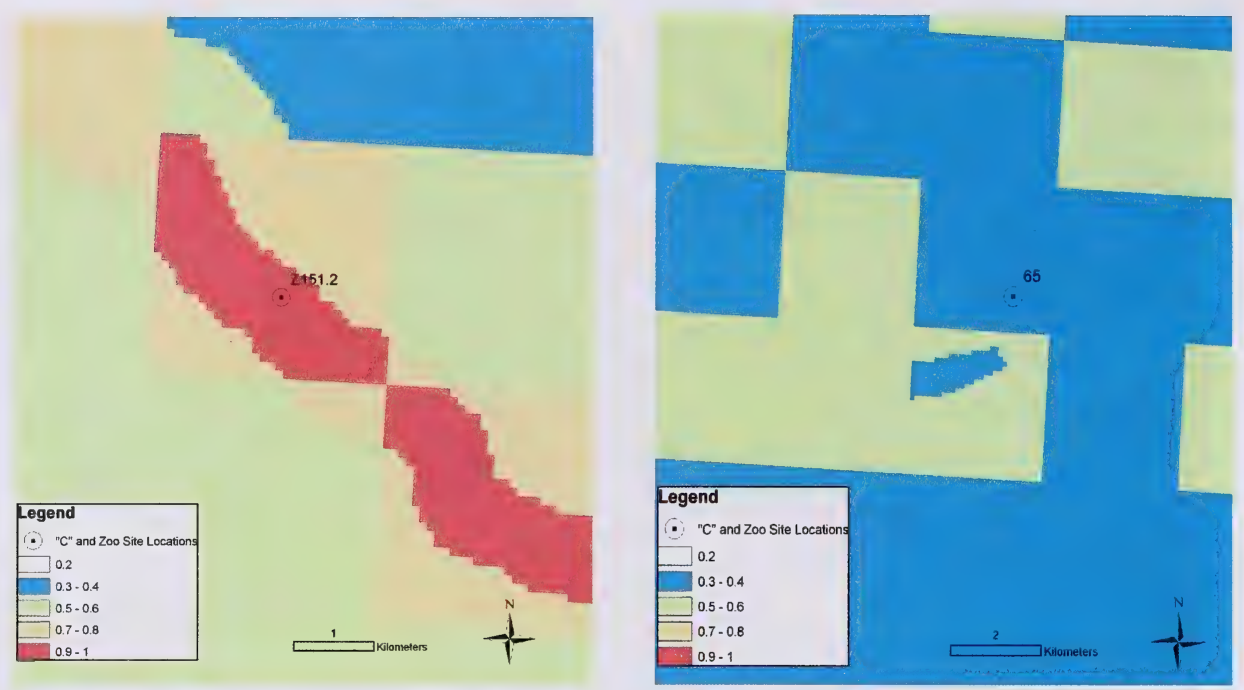

Figure 3. Example of HSI model validation, showing habitat value classes at point locations from historical observations where northern leopard frogs are currently present (left) or absent (right).

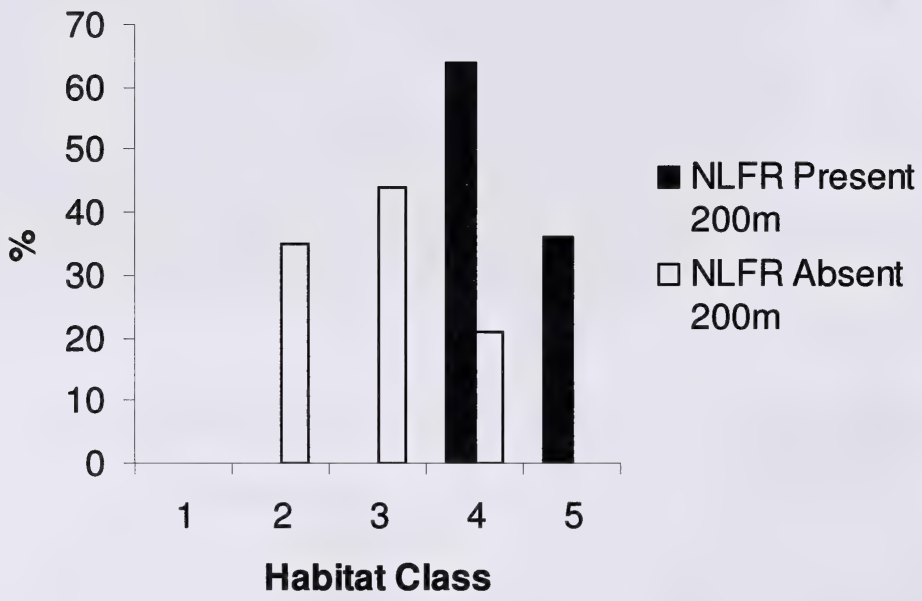

Figure 4. Proportion of northern leopard frog habitat value classes found within $200 \mathrm{~m}$ of historical sites where frogs were absent $(n=48)$ or present $(n=11)$. 


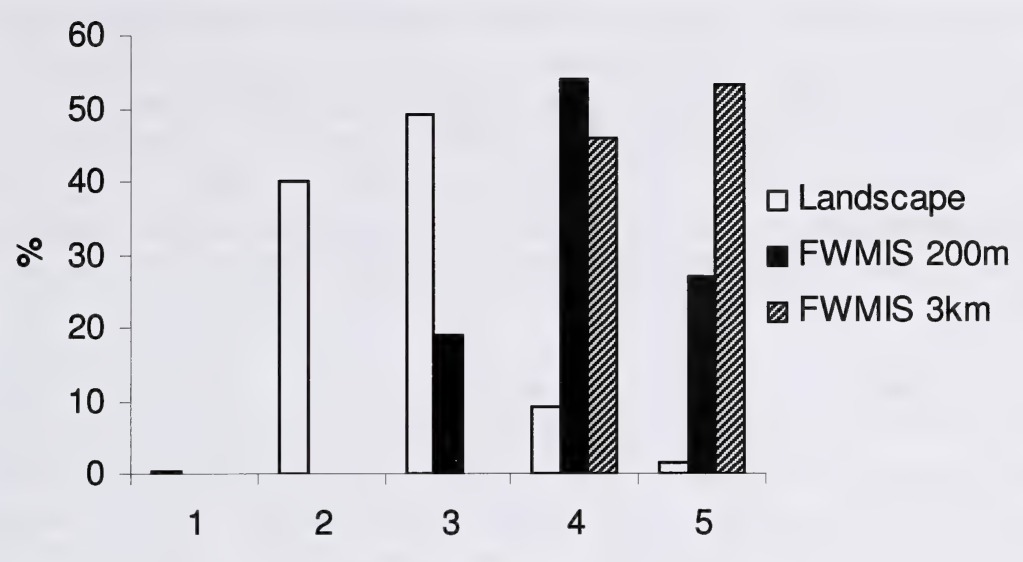

Habitat Class

Figure 5. Proportion of northern leopard frog habitat value classes found across current northern leopard frog range, within $200 \mathrm{~m}$ of new FWMIS observations ( $\mathrm{n}=26$; see text), and within $3 \mathrm{~km}$ of new FWMIS observations.

\subsection{DISCUSSION}

In 2005, a detailed population survey was undertaken to document the distribution and size of current northern leopard frog populations in Alberta (Kendell et al. 2007). This survey set the stage for a number of management and research initiatives undertaken in 2006, including the identification of potential egg mass source sites, assessment of reintroduction sites, implementation of stewardship projects, and development of the HSI model reported here. Comparison of occupied and unoccupied northern leopard frog sites from the 2005 survey showed differences in several GIS attributes including the presence of permanent hydrology, road density, climate, and vegetation characteristics. Changes in the landscape resulting in decreased natural vegetation regimes as a result of agricultural development (i.e. graminoid and wetland cover), decreased networks of permanent water as a result of water drainage and diversion, and increasing road density and habitat fragmentation may have resulted in historical populations of northern leopard frogs being extirpated (ASRD 2003). Basing the model on those variables should therefore reflect biological requirements of the species.

Although habitat models have been created for several species of amphibian (e.g., bull frog [Rana cateseiana], Graves and Anderson 1987; Columbia spotted frog [Rana pretiosa], Goldberg and Watts 2009, Pearl et al. 2009; long-toed salamander [Ambystoma macrodactyla], Goldberg and Watts 2009; Pacific tree frogs [Pseudacris regilla], Goldberg and Watts 2009, Timossi and Barret 1995a; yellow-legged frog [Rana boylii], Lind and Yarnell 2007, Timossi et al. 1995b) most occur at small landscape scales. We are not aware of any habitat suitability models for northern leopard frogs in Alberta. However, Blomquist and Hunter (2009) modeled habitat selection and movement patterns of northern leopard frogs in a managed forest in Maine, USA. Although habitat parameters for northern leopard frogs differ substantially between the forests of Maine 
and prairies of Alberta, they found that variables similar to those in our model tended to affect occupancy by northern leopard frogs: availability of standing water, canopy cover, soil moisture, and temperature. Further, Germaine and Hays (2009) created siteoccupancy models for northern leopard frogs in Washington at two scales: individual ponds and $1 \mathrm{~km}^{2}$. Similar to our study, they compared occupied and unoccupied sites to derive model parameters, and found that occupied sites had greater pond depth, more herbaceous vegetative cover and fewer neighboring ponds containing nonnative predatory fish.

There are several variables that could be used to fine-tune the model reported here, but which are not available as GIS data and that would be difficult to apply over large geographical areas. Some of these include: presence of predatory fish species, water depth, dissolved oxygen concentration, and concentration of pesticides and fertilizers. Those variables were examined at a course scale in this model by using parameters associated with permanent water (SL Net and hydropolygons) and road density (a possible indicator habitat fragmentation and, therefore, intensity of agriculture). Road density has been shown to have negative impacts on amphibian populations and has been used in other models of habitat conservation (e.g., Gunson et al. 2009).

Additional validation is desirable, but the model developed here appears to have some predictive power, given that habitat values are higher at historical sites where northern leopard frogs are present versus absent. Further, recent northern leopard frog sightings tend to be found in areas of high habitat value. Future surveys to find more northern leopard frog sites can focus on areas identified by the model to be of the highest habitat quality (i.e. "red" areas), since that habitat class is found in a higher proportion of new sites relative to its area over the landscape. Further, many of the sites in lower habitat quality classes (i.e. "orange" or "green" areas) were located within a $3 \mathrm{~km}$ proximity to red areas, as indicated by the increasing proportions in high habitat value classes from $200 \mathrm{~m}$ to $3 \mathrm{~km}$ (Figure 5). In summary, the model could be a useful tool for further determining status of the northern leopard frog in Alberta, and for promoting reintroduction efforts through the evaluation of habitat at potential recipient sites. 


\subsection{LITERATURE CITED}

Alberta Environmental Protection. 1996. The Wildlife Act. Alberta Environmental Protection, Natural Resources Service. 212 pp.

Alberta Northern Leopard Frog Recovery Team. 2005. Alberta Northern leopard frog Recovery Plan, 2005-2010. Alberta Sustainable Resource Development, Fish and Wildlife Division, Alberta Species at Risk Recovery Plan No. 7. Edmonton, AB. $26 \mathrm{pp}$.

Alberta Sustainable Resource Development. 2003. Status of the northern leopard frog in Alberta: update 2003. Alberta Sustainable Resource Development, Fish and Wildlife Division, and Alberta Conservation Association, Wildlife Status Report No. 9, Edmonton, AB. 61 pp.

Berry, K. 1986. Introduction: development, testing, and application of wildlife-habitat models. Pp. 3-10 in Wildlife 2000: modeling habitat relationships of terrestrial vertebrates (J. Verner et al., eds.). University of Wisconsin Press, Madison, WI.

Bessie, W., B. Beck, J. Beck, R. Bonar, and M. Todd. 1996. Development and use of HSI models. Pp. 1-9 in Habitat suitability index models for 35 wildlife species in the foothills model forest. Foothills Model Forest, Hinton, AB, Canada.

Blomquist, S.M. and M.L. Hunter. 2009. A multi-scale assessment of habitat selection and movement patterns by northern leopard frogs in a managed forest. Herpetological Conservation and Biology 4:142-160.

Carr, L.W. and L. Fahrig. 2001. Impact of road traffic on two amphibian species of differing vagility. Biological Conservation 15: 1071-1078.

COSEWIC 2002. Canadian species at risk, May 2002. Committee on the Status of Endangered Wildlife in Canada, Ottawa, ON. 32 pp.

Dayton, G.H. and L.A. Fitzgerald. 2005. Developing

Downey, B.A., B.L. Downey, R.W. Quinlan, O. Castelli, V.J. Remesz, and P.F. Jones (eds.). 2004. 2004 MULTISAR: the Milk River basin habitat suitability models for selected wildlife management species. Alberta Sustainable Resource Management, Fish and Wildlife Division, Alberta Species at Risk Report No. 86, Edmonton, AB. 135 pp.

Frisbie, M.D. and R.L. Wyman. 1982. The effect of soil chemistry on sodium balance in the red-backed salamander: a comparison of two forest types. Journal of herpetology 26:434-442. 
Germaine, S.S. and D.W. Hays. 2009. Distribution and postbreeding environmental relationships of northern leopard frogs (Rana [Lithobates] pipiens) in Washington. Western North American Naturalist. 69:537-547.

Goldberg, C.S. and L.P. Watts. 2009. Using habitat models to determine conservation priorities for pond-breeding amphibians in a privately-owned landscape of northern Idaho. Biological Conservation 142:1096-1104.

Graves, B.M. and S.H. Anderson. 1987. Habitat suitability models: bullfrog. US Fish and Wildlife Services Biological Report 82. 22 pp.

Gunson, K.E., Ireland, D., and F. Schueler. 2009. Incorporating road mortality hotspot modeling and connectivity analyses into road mitigation planning in Ontario. Proceedings of the 2009 international conference of ecology and transportation. $14 \mathrm{pp}$.

Hine, R.L., B.L. Les, and B.F. Hellmich. 1981. Leopard Frog populations and mortality in Wisconsin, 1974-76. Wisconsin Department of Natural Resources Technical Bulletin No. 122, Madison, WI. 39 pp.

Houlihan, J.E., Findlay, C.S., Schmidt, B.R., Meyers, A.H., and S.L. Kuzmin. 2001. Qualitative evidence for global amphibian population declines. Nature 404:752755.

Jones, P. 2004. Habitat suitability index model background. Pp. 2-7 in 2004 MULTISAR: the Milk River basin habitat suitability models for selected wildlife management species (B.A. Downey, B.L. Downey, R.W. Quinlan, O. Castelli, V.J. Remesz and P.F. Jones, eds.). Alberta Sustainable Resource Management, Fish and Wildlife Division, Alberta Species at Risk Report No. 86, Edmonton, AB.

Kendell, K. 2002. Survey protocol for the northern leopard frog. Alberta Sustainable Resource Development, Fish and Wildlife Division, Alberta Species at Risk Report No. 43, Edmonton, AB. 30 pp.

Kendell, K., Stevens, S., and D. Prescott. 2007. Alberta Northern Leopard Frog Survey, 2005. Technical Report, D-2006-000, produced by Alberta Conservation Association, Edmonton, Alberta, Canada. 33 pp.

Lind, A. and S. Yarnell. 2007. Habitat suitability criteria for the foothill yellow-legged frog (Rana boylii) in the northern Sierra Nevada and Coast ranges of California. Unpublished Report for the foothill yellow-legged frog habitat suitability technical working group. $40 \mathrm{pp}$.

Mazerolle, M., Desrochers, A., and L. Rochefort. 2005. Landscape characteristics influence pond occupancy by frogs after accounting for detectability. Ecological Applications 15:824-834. 
Mazerolle, M. and M. Villard. 1999. Patch characteristics and landscape context as predictors of species presence and abundance: A review. Ecoscience 6:117-124.

Merrell, D.J. 1977. Life history of the Leopard Frog, Rana pipiens, in Minnesota. Bell Museum of Natural History, University of Minnesota, Minneapolis, MN.

Morrison, M.L., B.G. Marcot, and R.W. Mannan. 1992. Wildlife-habitat relationships: concepts and applications. The University of Wisconsin Press, Madison, WI. 343 pp.

Pearl, C.A., Adams, M.J., and N. Leuthold. 2009. Breeding habitat and local population size of the Oregon spotted frog (Rana pretiosa) in Oregon, USA. Northwestern Naturalist 9:136-147.

Piha, H., Luoto, M., and J. Merilä. 2007. Amphibian occurrence is influenced by current and historic landscape characteristics. Ecological Applications 17:2298-2309.

Pope, S.E., L. Fahrig, and H.G. Merriam. 2000. Landscape complementation and metapopulation effects on leopard frog populations. Ecology 81(9): 2498-2508.

Roberts, W. E. 1981. What happened to the Northern leopard frog? Alberta Naturalist 11: $1-4$

Seburn, C.N.L., Seburn, D.C., and C.A. Paszkowski. 1997. Northern leopard frog (Rana pipiens) dispersal in relation to habitat. In Amphibians in decline: Canadian studies of a global problem (D.M. Green, ed.). Herpetological Conservation 1: 6472.

Souder, W. 2000. A plague of frogs: the horrifying true story. Library of Congress Cataloguing-in-Publication, New York, NY. 299 pp.

Timossi, I.C., Woodard, E.L., and R.H. Barrett. 1995a. Habitat suitability models for use with ARC/INFO: Pacific tree frog. California Department of Fish and Game CWHR Program, Sacramento CA. CWHR Technical Report No. 11. 15 pp.

Timossi, I.C., Woodard, E.L., and R.H. Barrett. 1995b. Habitat suitability models for use with ARC/INFO: Mountain yellow-legged frog. California Department of Fish and Game CWHR Program, Sacramento CA. CWHR Technical Report No. 11. $11 \mathrm{pp}$.

USDI Fish and Wildlife Service. 1981. Standards for the development of suitability index models. U.S. Fish and Wildlife Service, Division of Ecological Services, 
Washington, D.C., Division of Ecological Services, Washington, D.C., Ecological Services Manual 103.

Wagner, G. 1997. Status of the Northern Leopard Frog (Rana pipiens) in Alberta. Alberta Environmental Protection, Wildlife Management Division, Wildlife Status Report No. 9, Edmonton, AB. 46 pp.

Wershler, C.R. 1992. Northern leopard frog monitoring-1991. Unpublished report by Sweetgrass Consultants Ltd. for World Wildlife Fund Canada (Prairie for Tomorrow) and Alberta Forestry, Lands and Wildlife, Edmonton, AB. 47+ pp.

Yaremko, L. 1994. Northern Leopard Frog project-field report 1994. Unpublished report for Fish and Wildlife Services, Edmonton, AB. 85 pp. 
For a list of additional reports in the Alberta Fish and Wildlife Division - Species at Risk Series please go to our website:

$\underline{\text { http://srd.alberta.ca/BioDiversityStewardship/SpeciesAtRisk/ProgramReports:aspx }}$ 


